\title{
HUBUNGAN SPIRITUALITAS DAN KUALITAS KEHIDUPAN KERJA PERAWAT DENGAN KEPUASAN KERJA PERAWAT DI RUANG RAWAT INAP RUMAH SAKIT UMUM DAERAH ANDI MUHAMMAD PARIKESIT TENGGARONG
}

\author{
Relationship Of Nurse's Spirituality And Quality Of Work Life With Nurse's Job Satisfaction \\ In Inpatient Ward At Rsud Parikesit Tenggarong
}

\author{
Maridi M. Dirdjo ${ }^{1}$, Widia Nur Kartika Sari' ${ }^{2}$, Zahratul Qolbi Ula Alfitri ${ }^{3}$ \\ ${ }^{1}$ Dosen Prodi Ilmu Keperawatan Fakultas Ilmu Kesehatan UMKT \\ ${ }^{2,3}$ Mahasiswa Prodi Ilmu Keperawatan Fakultas Ilmu Kesehatan UMKT
}

\begin{abstract}
ABSTRAK
Latar Belakang: Aspek spiritualitas dapat menjadikan seseorang lebih bisa memaknai arti kehidupan dan memiliki penerimaan diri terhadap kondisi apapun sehingga memberikan respon positif terhadap perubahan-perubahan yang terjadi pada dirinya. Memiliki spiritualitas yang tinggi akan menjadikan seseorang lebih kreatif dalam menentukan hal-hal yang bersifat intrapersonal dan interpersonal, serta dapat meningkatkan kepuasan kerja. Apalagi jika diikuti oleh dengan perbaikan kualitas kehidupan kerja perawat, sehingga memberi kesempatan untuk mereka untuk berkembang menggunakan keterampilan dan kompetensinya, adanya hubungan yang baik, partisipasi kerja, serta lingkungan kerja yang kondusif dapat memberikan kepuasan kerja perawat sehingga dapat meningkatkan produktivitas bagi rumah sakit.

Tujuan Penelitian : Penelitian ini bertujuan untuk mengetahui hubungan spiritualitas dan kualitas kehidupan kerja perawat dengan kepuasan kerja perawat di ruang rawat inap RSUD AM Parikesit Tenggarong.

Metode Penelitian : Rancangan penelitian ini menggunakan descriptive correlation dengan pendekatan cross sectional. Varibel penelitian diukur melalui kuesioner yang menggunakan The Quality Of Nursing Work Life Scale (Beth A, 2001) untuk kualitas kehidupan kerja perawat dan Index Of Work Satisfaction (Stamp, 1997) untuk kepuasan kerja perawat, sementara spiritualitas menggunakan kuesioner yang dikembangkan sendiri oleh penelitian sebanyak 16 item pernyataan dan telah dinyatakan valid dan reliabel. Teknik sampling yang digunakan adalah proportionate stratified random sampling berjumlah 109 orang. Analisis data dengan menggunakan uji parametrik person product moment.

Hasil Penelitian : Hasil uji stastitic didapatkan nilai $p$ value spiritualitas 0.193 dan kualitas kehidupan kerja 0,04. yang berarti tidak ada hubungan signifikan antara spiritualitas perawat dengan kepuasan kerja perawat tetapi memiliki arah hubungan yang positif. Sementara ada hubungan yang bermakna kualitas kehidupan kerja dengan kepuasan kerja perawat, berpola positif. Kesimpulan: Kebutuhan spiritualitas masih harus ditingkatkan sebab akan menjadi aspek penting dalam proses keperawatan yang tidak hanya untuk sesama perawat tetapi juga untuk klien. Disamping itu, kualitas kehidupan kerja perawat harus dipertahankan dan ditingkatkan lagi. Manajemen rumah sakit disarankan memfasilitasi pembelajaran formal dan informal dalam kerjasama tim terkait pemahaman spiritualitas, dan memperbaiki kondisi kerja di lingkungan keperawatan.
\end{abstract}

Kata kunci: Kepuasan Kerja Perawat, Spiritualitas, Kualitas Kehidupan Kerja Perawat, Rumah Sakit

\section{ABSTRACT}

Background: Aspects of spirituality can make a person more able to interpret the meaning of life and have self-acceptance of any condition so as to give a positive response to the changes that occur in him. Having a high spirituality will make a person more creative in determining things that are intrapersonal and interpersonal, and can increase job satisfaction. Moreover, if followed by improving the quality of work life of nurses, so that the opportunity for them to develop using their 
skills and competence, good relationships, work participation, and a conducive working environment can provide nurse's work satisfaction so as to increase productivity for the hospital.

Research Objectives: This study aims to determine the relationship between the nurse's spirituality and quality of work life with job satisfaction of nurses at inpatient wards of RSUD AM Parikesit Tenggarong.

Research Method: This research design used descriptive correlation with cross sectional approach. The research variables were measured through questionnaires using The Quality of Nursing Work Life Scale (Beth A, 2001) for the quality of nurse's work life and Index Of Work Satisfaction (Stamp, 1997) for nurse's job satisfaction, while spirituality used self-developed questionnaires 16 item statement and has been declared valid and reliable. The sampling technique used was proportionate stratified random sampling of 109 people. Data analysis was by using parametric test person product moment.

Result: The result of stastitic test got p value of spirituality 0.193 and quality of work life 0.04. Which means there is no significant relationship between the nurse's spirituality with the nurse's job satisfaction but has a positive relationship direction. While there is a significant relationship quality of work life with job satisfaction of nurse, patterned positive.

Conclusion: The need for spirituality still needs to be improved because it becomes an important aspect in the nursing process that is not only for the same nurse but also for the client. In addition, the quality of work life of the nurse must be maintained and enhanced again. Hospital management is recommended to facilitate formal and informal learning in teamwork related to understanding spirituality, and improve working conditions in the nursing environment.

Keywords: Job Satisfaction of Nurses, Spirituality, Quality of Work Life of Nurses, Hospital

\section{PENDAHULUAN}

World Health Organization (WHO) pada tahun 2006 melaporkan telah terjadi krisis tenaga kesehatan secara global (Baumann, 2007), seperti kekurangan tenaga perawat termasuk negara maju seperti Amerika Serikat (Amendolair 2007), negara lainnya termasuk Australia (Eley, dkk., 2010). Kondisi tersebut salah satu penyebabnya adalah masalah rendahnya kepuasan kerja perawat.

Kepuasan kerja perawat itu sendiri dipengaruhi oleh banyak faktor, salah satunya beban kerja yang tinggi. Perawat dituntut memperhatikan dan memberikan asuhan individu sebagai makhluk bio-psiko-sosio-spiritual yang berespon secara holistik dan unik terhadap perubahan kesehatan yang terjadi (Dossey, Keegan, Guzzetta, 2005). Beban kerja yang besar meningkatkan stress kerja. Apalagi jika bekerja dalam kondisi kerja yang masih belum baik.

Kepuasan kerja sudah menjadi unsur yang penting dalam dunia kerja baik itu dalam dunia kerja di bidang industry pelayanan kesehatan termasuk keperawatan. Maka diperlukan tenaga keperawatan yang tangguh yang memiliki motivasi kerja yang tinggi yang didukung oleh spiritualitas yang memadai.

Spiritualitas berpengaruh terhadap mekanisme koping seseorang, sehingga sesorang harus mengasah kemampuan spiritual guna membangun mekanisme koping yang konstruktif. Perkembangan yang baik dalam aspek spiritual dapat menjadikan seseorang lebih bisa memaknai kehidupan dan memiliki penerimaan diri terhadap kondisinya sehingga memberikan respon positif terhadap perubahan-perubahan yang terjadi pada dirinya (Nurmaafi, 2013 dalam Putra, 2014).

Aspek spiritualitas dapat menjadikan seseorang lebih bisa memaknai arti kehidupan dan memiliki penerimaan diri terhadap kondisi apapun sehingga memberikan respon positif terhadap perubahan-perubahan yang terjadi pada dirinya. Memiliki spiritualitas yang tinggi akan menjadikan seseorang lebih kreatif dalam menentukan hal-hal yang bersifat intrapersonal dan interpersonal, serta dapat meningkatkan kepuasan kerja.

Disamping hal tersebut diatas, kepuasan kerja menurut Wasis (2008), merupakan perasaan yang menyokong untuk mendapatkan hasil kerja yang optimal ketika seorang perawat merasakan kepuasan dalam bekerja, tentunya dia akan berusaha semaksimal mungkin untuk dapat menyelesaikan pekerjaannya. Namun demikian, saat ini rumah sakit justru mengalami berbagai 
masalah yang berhubungan dengan tenaga keperawatan dan pelayanan keperawatan. Masalahmasalah tersebut berhubungan dengan kekurangan jumlah perawat, ketidakpuasan kerja perawat dan buruknya lingkungan kerja perawat (Wuryanto, Hamid dan Mustikasari, 2011).

Namun, perbaikan lingkungan kerja bagi perawat belum menjadi menjadi prioritas para pimpinan rumah sakit. Para menajer rumah sakit masih berfokus pada upaya pencapaian kepuasan pelanggan eksternal dan mengabaikan kepuasan pelanggan eksternal. Padahal, kepuasan pelangan eksternal akan sulit ercapai jika kepuasan pelanggan internal belum tercapai (Maridi, 2006).

Kondisi lingkungan kerja yang baik akan memperbaiki kualitas kehidupan kerja perawat. Perbaikan kualitas kehidupan kerja perawat akam memberi kesempatan untuk mereka untuk berkembang menggunakan keterampilan dan kompetensinya, adanya hubungan yang baik, partisipasi kerja, serta lingkungan kerja yang kondusif dapat memberikan kepuasan kerja perawat sehingga dapat meningkatkan produktivitas bagi rumah sakit.

Dari studi pendahuluan yang dilakukan pada bulan Februari 2017, di dapatkan hasil wawancara dengan data bahwa 5 dari 10 perawat atau $50 \%$ perawat pelaksana mengatakan bahwa spiritualitasnya baik, dengan mengajukan 6 item pertanyaan sesuai indikator spiritualitas tentang hubungan perawat dengan Tuhan-nya, spiritualitas perawat dalam bekerja seperti hubungan perawat dengan teman perawat lainnya, perawat dengan atasannya, perawat dengan diri sendiri, motivasi perawat dalam bekerja, dan seberapa nyaman perawat berkolabarasi dengan perawat lainnya. Dimana pemenuhan spiritualitas diruangan telah dilakukan oleh beberapa perawat tetapi belum maksimal dilaksanakan sepenuhnya oleh semua perawat.

Wawancara terstruktur didapati ada $7(70 \%)$ dari $10(100 \%)$ perawat mengatakan mereka senang dengan lingkungan kerja di Rumah Sakit dalam bekerjasama dengan perawat lainnya, komunikasi sesama pegawai berjalan dengan baik dan dapat berkolaborasi dengan efisien bersama tim kesehatan yang lain. Hubungan dengan atasan juga terjalin dengan baik, untuk persepsi pekerjaan sendiri perawat merasa puas dengan apa yang dikerjakan karena perawat memiliki hak untuk memutuskan perawatan untuk pasien serta didukung oleh kerjasama tim yang baik, namun untuk kondisi pekerjaan $3(30 \%)$ perawat dari $10(100 \%)$ perawat mengatakan mereka terlalu banyak bekerja dikarenakan jumlah perawat yang masih kurang di setiap ruangan tidak sebanding dengan banyaknya pasien serta dukungan jasa yang belum terpenuhi seperti alat-alat medis perawat merasa bahwa alat yang disediakan oleh rumah sakit masih kurang memadai untuk kesembuhan pasien.

Hasil wawancara didapatkan juga data bahwa 6 dari 10 atau $60 \%$ perawat pelaksana mengatakan tidak puas terhadap otonomi, tuntutan tugas dan kebijakan organisasi, sedangkan berdasarkan teori terdapat 6 sub variabel untuk mengukur kepuasan kerja perawat yang berguna untuk menjaga dan meningkatkan mutu pelayanan kesehatan. Sehingga dari uraian latar belakang diatas, peneliti tertarik untuk melakukan penelitian tentang hubungan spiritualitas dan kualitas kehidupan kerja perawat dengan kepuasan kerja perawat.

\section{TUJUAN PENELITIAN}

Penelitian ini bertujuan untuk mengetahui hubungan spiritualitas dan kualitas kehidupan kerja perawat dengan kepuasan kerja perawat ruang rawat inap di RSUD Aji Muhammad Parikesit Tenggarong

\section{METODE PENELITIAN}

Penelitian ini menggunakan rancangan penelitian descriptive correlation dengan pendekatan cross sectional. Populasi pada penelitian ini adalah adalah seluruh perawat diruang rawat inap di A.M Parikesit Tenggarong sebanyak 150 orang perawat. Teknik sampling dalam penelitian ini menggunakan teknik sampling proportionate stratified random sampling. Berdasarkan perhitungan rumus Slovin didapatkan hasil 109 responden. Kriteria inklusi dalam penelitian ini adalah perawat yang bertugas sebagai perawat pelaksana diruang kelas 1, 2 dan 3, bersedia menjadi responden dan perawat yang berkerja selama $\geq 1$ tahun. Sedangkan kriterian eklusi adalah perawat yang bertugas di ruang IGD, UPI, VVIP dan VIP, perawat yang sedang sakit atau cuti dan perawat yang sedang mengikuti pendidikan dan pelatihan selama masa pengambilan data.

Varibel penelitian diukur melalui kuesioner yang menggunakan The Quality Of Nursing Work Life 
Scale (Brooks, dkk., 2007) untuk kualitas kehidupan kerja perawat dan Index Of Work Satisfaction (Stamp, 1997) untuk kepuasan kerja perawat, sementara spiritualitas menggunakan kuesioner yang dikembangkan sendiri oleh penelitian sebanyak 16 item pernyataan dan telah dinyatakan valid dan reliabel.

Hubungan spiritualitas dan kuulitas kehidupan kerja perawat dengan kepuasan kerja perawat menggunakan Uji statistik pearson product moment setelah data dilakukan uji normalitas. Hasil uji normalitas ketiga variable berdistribusi normal.

\section{HASIL PENELITIAN}

1. Analisis univariat

a. Karakteristik Responden

Karakteristik responden penelitian ini dapat dilihat pada tabel 1 berikut:

Tabel 1 Distribusi Responden berdasarkan usia, jenis kelamin, status perkawinan, pendidikan, masa kerja, Ruang Rawat Inap RSUD AM Parikesit Tenggarong

\begin{tabular}{lccc}
\hline & Kategorl & Frekuensi & $\begin{array}{c}\text { Persentase } \\
(\%)\end{array}$ \\
\hline Usia & $20-30$ & 104 & 95.4 \\
Jenis & $31-40$ & 5 & 4.6 \\
kelamin & Perempuan & 48 & 44.0 \\
\hline Perkawinan & Belum Menikah & 51 & 56.0 \\
\hline Pendidikan & Menikah & 57 & 47.0 \\
& D4 & 94 & 52.3 \\
\hline Lama Kerja & $\leq 3$ tahun & 2 & 8.2 \\
& $\geq 1$ tahun & 61 & 1.8 \\
& $\geq 3$ tahun & 48 & 56.0 \\
\hline
\end{tabular}

Responden penelitian ini sebagian besar kelompok umur 20-30 tahun sebanyak 95\%. Jenis kelamin sebagian besar berjenis kelamin perempuan 56\%. Status perkawinan sebagian besar menikah sebanyak 52.3\%, dan pendidikan sebagian besar D3 (86.2\%). Lama kerja sebagian besar <3 tahun sebanyak 61 orang $(56.0 \%)$, dan

b. Nilai Spiritualitas

Tabel 2 Skor spiritualitas Perawat di Ruang Rawat Inap RSUD AM Parikesit Tenggarong

\begin{tabular}{llllll}
\hline Variabel & Mean & ME & SE & SD & N \\
\hline $\begin{array}{l}\text { Spiritualitas } \\
\text { perawat }\end{array}$ & 69.91 & 69.00 & 0.467 & 4.878 & 109
\end{tabular}

Data diatas menunjukan bahwa spiritualitas perawat didapatkan dengan nilai mean 69.61. median 69.00 dengan nilai standar error 0.467 standar deviasi 4.878 .

c. Kualitas Kehidupan Kerja Perawat

Tabel 3 Skor Kualitas Kehidupan Kerja Perawat di Ruang Rawat Inap RSUD AM Parikesit

Tenggarong

\begin{tabular}{cccccc}
\hline Variabel & Mean & Median & SD & SE & n \\
\hline KKK & 135,3 & 133,00 & 9,599 & & 109 \\
\hline \multicolumn{2}{l}{ KKK: Kualitas Kehidupan Kerja } & & &
\end{tabular}

Tabel 3 diatas menunjukkan bahwa distribusi deskriptif kualitas kehidupan kerja memiliki skor rata-rata 133,51 
d. Kepuasan kerja

Tabel 4 Skor Kepuasan Kerja Perawat d i Ruang Rawat Inap RSUD AM Parikesit Tenggarong

\begin{tabular}{lllllc}
\hline Variabel & Mean & ME & SE & SD & N \\
\hline $\begin{array}{l}\text { Kepuasan } \\
\text { Kerja }\end{array}$ & 157.90 & 157.00 & 1.323 & 13.816 & 109 \\
\hline $\begin{array}{l}\text { Data diatas menunjukan bahwa kepuasan kerja perawat didapatkan dengan nilai } \\
\text { mean 157.90, median 157.00 dengan nilai standar error 1.323, standar deviasi 13.816. }\end{array}$
\end{tabular}

2. Bivariat

Hubungan spiritualitas dan Kualitas kehidupan kerja perawat dengan kepuasan kerja dapat dilihat pada tabel 5 berikut ini.

Tabel 5 Hubungan spiritualitas dan kualitas kehidupan kerja dengan Kepuasan Kerja Perawat d i Ruang Rawat Inap RSUD AM Parikesit Tenggarong

\begin{tabular}{lccc}
\multicolumn{1}{c}{ Variabel } & r & P value & n \\
\cline { 1 - 3 } Spiritualitas & 0,193 & 0,126 & \multirow{2}{*}{109} \\
\cline { 1 - 3 } Kualitas Kehidupan kerja & 0,275 & 0,004 & \\
\hline Dependen: Kepuasan Kerja Perawat & &
\end{tabular}

Berdasarkan analisa data antara spiritualitas dengan kepuasan kerja perawat didapatkan hasil $p$ value 0.193, yang lebih besar dari alfa (0.05) sehingga dapat disimpulkan tidak ada hubungan antara spritualitas dengan kepuasan kerja perawat, hubungan bersifat lemah dan berpola positif. Tabel diatas juga menunjukkan hubungan kualitas kehidupan kerja dengan kepuasan kerja, diperoleh nilai p-value 0,004 yang menunjukkan bahwa korelasi antara Hubungan Kualitas Kehidupan Kerja Perawat dengan Kepuasan kerja Perawat, hubungan dengan kekuatan sedang dan berpola positif.

\section{PEMBAHASAN}

Hasil penelitian ini menemukan tidak ada hubungan signifikan antara spritualitas perawat dengan kepuasan kerja perawat. Hasil ini sejalan dengan hasil penelitian Rahman dan Makmur (2015) yang menemukan bahwa spiritualitas baik perilaku spiritual tidak berpengaruh langsung terhadap kepuasan kerja karyawan tidak signifikan. Tetapi kecerdasan spiritual berpengaruh signifikan terhadap kepuasan kerja karyawan. Hal ini berarti perilaku spiritual ini terkait dengan religiusitas seseorang dan kecerdasan spiritual terkait dengan nilai-nilai spiritualitas yang dimiliki orang tersebut.

Spiritualitas sendiri berbeda dengan religiusitas. [Spiritualitas] ". . sistem kepercayaan atau nilai yang menembus semua kehidupan seseorang, memberi makna hidup dalam konteks enam hubungan dasar manusia: 1) kepada Tuhan, atau siapapun atau apapun yang dianggap sebagai realitas tertinggi, 2) untuk diri sendiri, 3) kepada orang lain, 4 ) ke lingkungan, 5) ke masa lalu, dan 6) ke masa depan "(Hoshiko, 1994, hal 5, dalam Westera, 2017). Spiritualitas ini merupakan semangat keagamaan yang dimiliki seseorang yang dibawa seseorang untuk beraktivitas dalam kehidupan sehari-hari termasuk dibawa ke tempat kerja. Ilmuwan sosial menggunakan istilah religiusitas untuk menunjukkan intensitas dan komitmen praktik individu atau partisipasi dalam menjalankan agamanya (Gay \& Lynxwiler, 2013).

Spiritualitas ternyata sangat penting dalam kehidupan karyawan yang bekerja dalam sebuah 
organisasi, tidak terkecuali perawat. Negara barat, para manajer dimasa lalu telah mengabaikan pentingnya spiritualitas seseorang untuk meningkatkan kinerja organisasi. Namun saat ini kesadaran penting spiritualitas muncul kembali. Certo dan Certo (2016: 411) menyatakan, "Spiritualitas merupakan salah satu dimensi dari budaya organisasi modern, disamping ada dimensi lain seperti kualitas, etika, inovasi, keberagaman dan pelanggan. Walaupun budaya organisasi tidak harus mencakup dimensi-dimensi tersebut, namun ada kecenderungan para manajer untuk menggunakan dimensi-dimensi tersebut untuk meningkaktan kesuksesan organisasi. Berdasarkan pendapat ini, manajemen rumah sakit penting menggalakan semangat spiritualitas tenaga kesehatan untuk meningkatkan kepuasan kerja dan kinerjanya. Spiritualitas ini harus mejadi budaya organisasi. Spititualitas dalam pandangan budaya organisasi adalah mengintegrasikan kehidupan spiritual dengan kehidupan kerja (Certo \& Certo, 2016: 412).

Tidak adanya hubungan spiritualitas perawat dengan kepuasan kerjanya menunjukkan masih perlu ditingkatkan nilai-nilai spiritualitas perawat yang bekerja dirumah sakit. Hal ini dapat dilakukan dengan melakukan pelatihan ESQ bagi perawat secara periodic untuk tetap menggelorakan semangat spiritual dalam bekerja sehingga menumbuhkan kinerja yang lebih baik lagi. Tujuan utamanya adalah meningkatkan kecerdasan spiritual perawat. Karyawan yang cerdas spiritual melahirkan perilaku yang tenang, memandang pekerjaan sebagai sesuatu yang bernilai dan bermakna positif, sehingga dengan itu mereka akan cenderung puas dalam bekerja (Rahman \& Makmur, 2015).

Disamping itu, masih perlu dikembangkan kuesioner atau tool untuk menilai spiritual karyawan/ perawat. Menurut teori yang dikemukakan oleh Taylor, et al (1997), nilai dari keyakinan spiritualitas tidak dapat dengan mudah dievaluasi. Walaupun demikian pengaruh spiritualitas dapat diamati oleh tenaga kesehatan dengan mengetahui bahwa individu cenderung dapat menahan distress fisik maupun batin yang luar biasa karena mempunyai keyakinan yang kuat, atau dengan kata lain karyawan telah memiliki nilai-nilai spiritual yang baik.

Spiritualitas seseorang ternyata mampu memberi jawaban terhadap masalah-masalah terkini yang rumit dikarenakan oleh perubahan besar dalam organisasi (Benefiel, Fry \& Geigle, 2014). Nilai-nilai spiritual yang mendasari kerja perawat dapat dijadikan modal utama untuk bekerja, terutama untuk mengatasi masalah yang berat dan mampu menerima hasil kerjanya, apapun hasilnya tersebut. Kemampuan untuk menerima inilah yang menjadi cikal bakal kepuasan kerja seseorang. Kepuasan kerja tidak hanya berasal dari materi yang yang didapat oleh perawat sebagai karyawan, tetapi bisa didapat dari kepuasan bathin karena dapat berguna untuk orang lain dan senang memberi pertolongan kepada orang lain, apalagi pada pasien yang sedang menderita sakit tertentu. Kepuasan semacam ini tidak mungkin didapat jika spiritualitas seseorang masih dangkal. Pendapat peneliti didukung oleh hasil penelitain Lazar (2010) yang menyimpulkan ada hubungan positif antara aspek kehidupan spiritualitas dan nilai spiritual dengan kepuasan kerja.

Penting juga dikembangkan spiritualitas di tempat kerja (workplace spirituality), yaitu sebuah budaya di mana nilai-nilai organisasi dapat meningkatkan rasa bermakna dalam bekerja (Robbins \& Coulter, 2017: 120). Beberapa karakteristik budaya cenderung muncul dalam organisasi spiritual, seperti: (1) Kebajikan, organisasi spiritual memberi nilai kebaikan kepada orang lain dan kebahagiaan karyawan serta pemangku kepentingan lainnya; (2) Diarahkan pada tujuan yang kuat, organisasi spiritual membangun budaya untuk mencapai tujuan bermakna termasuk untuk meraih keuntungan, walaupun hal ini penting, tetapi bukan tujuan utama, (3) Kepercayaan dan penghormatan. organisasi spiritual ini dicirikan oleh rasa saling percaya, kejujuran, dan keterbukaan. Karyawan diperlakukan sebagai manusia yang memiliki harga diri dan nilai, sesuai dengan martabat masing-masing individu, dan (4) Keterbukaan wawasan/ pikiran, dimana organisasi spiritual menghargai pemikiran dan kreativitas yang fleksibel di antara karyawan (Robbins \& Judge, 2017)

Namun demikian, kepuasan kerja perawat tidak hanya dipengaruhi oleh spiritualitas saja tetapi kondisi kerja perawat sebagai karyawan sebuah rumah sakit, dalam bentuk kualitas kehidupan kerja perawat. Pada penelitian ini didapatkan ada hubungan bermakna antara kualitas kehidupan kerja dengan kerpuasan kerja perawat. Hasil ini konsisten dengan hasil-hasil temuan penelitian sebelumnya, seperti yang dilaporkan oleh Nekouei, Othman \& Ahmad, 2014; Kermansaravi, Navidian, Rigi \& Yaghoubinia, 2015; Fatehi, Amini, Karimi, \& Azizi, 2015; dan 
Bhatnagar, \& Soni, 2015).

Terkait hasil tersebut diatas, agar karyawan rumah sakit termasuk perawat merasa puas dalam kehidupan kerjanya maka kualitas kehidupan kerjanya harus diperbaikan, karena kepuasan kerja itu sendiri sebagai akibat atau hasil dari kualitas kehidupan kerja (Ramawickrama, Opatha \& Pushpakumari, 2017). Para pakar manajemen serta peneliti juga sepakat bahwa kualitas kehidupan kerja merupakan variabel yang penting sejak ditemukan bukti yang menunjukkan bahwa lingkungan kerja terkait erat dengan kepuasan karyawan dan terkait pula dengan perilaku bekerja karyawan (Sinha, 2012). Oleh sebab itu, peneliti menyarakan kepada managemen rumah sakit untuk mengukur secara periodik kualitas kehidupan kerja perawat dan melakukan upaya-upaya peningkatrannya, karena peningkatan kualitas barang atau jasa bermula dari perbaikan kualitas kehidupan kerja (Alzalabani, 2017). Disamping itu, kualitas kehidupan kerja perawat dapat memberikan kepuasan dan meningkatkan kinerja perawat (Gayathiri \& Ramakrishnan, 2013). Untuk itu, perlu dikembangkan meningkatkan kualitas kehidupan kerja oleh rumah sakit.

Program kualitas kehidupan kerja ( $Q W L$ programs) adalah program yang menciptakan lingkungan kerja yang meningkatan kesejahteraan dan kepuasan karyawan (Bateman \& Snell, 2014). Tujuan umumnya adalah memuaskan kebutuhan semua karyawan. Melalui program peningkatan kualitas kehidupan kerja ini, diharapkan akan meningkatkan martabat semua karyawan, memperkenalkan perubahan budaya organisasi, dan meningkatan kesejateraan fisik dan emosional karyawan (Ivancevich, Konopaske \& Matteson, 2014: 143; Konopaske, Ivancevich \& Matteson, 2018). Program yang harus dikembangkan terutama keseimbangan hidup antara kerja dan non kerja, kesehatan dan kesejahteraan, kemanan kerja dan pengembangan kompetensi (Reddy \& Reddy, 2010).

\section{KESIMPULAN}

Hasil penelitian dapat disimpulkan bahwa :

1. Spiritualitas perawat tidak ada hubungan yang bermakna dengan kepuasan kerja perawat adalah ( $p$ value 0.193 ), hubungannya lemah dan berpola positif.

2. Kualitas kehdupan keprja perawat berhungan bermakna dengan kepuasan kepuasan kerja perawat (p value 0,04$)$.

\section{SARAN}

Manajemen rumah sakit terutama bidang sumberdaya manusia sangat penting mengembangkan spiritualitas di tempat kerja (Rumah sakit). Dapat dilakukan dengan melakukan pelatihan Emotional Spiritual Question (ESQ) yang periodik. Para perawat juga memelihara dan mengembangkan spiritualias pribadinya untuk meningkatkan kinerja dan layanan kepada pasien yang dilayani. Manajemen sakit juga disarankan terus memperbaiki kualitas kehidupan kerja perawat terutama keseimbangan hidup antara kerja dan non kerja, kesehatan dan kesejahteraan, kemanan kerja dan pengembangan kompetensi.

\section{DAFTAR PUSTAKA}

Alzalabani, A.H., (2017) A Study on Perception of Quality of Work Life and Job Satisfaction: Evidence from Saudi Arabia. Arabian J Bus Manag Review 7(2): 294-313

Amendolair, D. (2007). Caring behaviors and job satisfaction: A study of registered nurses in medical surgical units in North and South Carolina acute care hospitals, Doctoral dissertation. Retrieved from ProQuest Dissertations and Theses database. (3274983).

Bateman, T. S., \& Snell, S. A., (2015). Manajemen, Kepemimpinan da Kerjasama dalam Dunia yang Kompetitif, (10th edition), Jakarta: Salemba Empat

Baumann A. (2007). Positive Practice Environments: Quality Workplaces. Geneva (Switzerland): ICN-International Council of Nurses; Retrieved from http://www.icn.ch/images/stories/documents/publications/ind/indkit 2007.pdf

Benefiel, M., Fry, L.W., \& Geigle, D., (2014). Spirituality and Religion in the Workplace: History, Theory, and Research, Psychology of Religion and Spirituality, 6(3): 175-187 
Brooks \& Anderson. (2015). Quality of Nursing Work Life Scale: The Psychometric Evaluation of the Turkish Version. Di akses tanggal 2 Januari 2017 www.internationaljournalofcaringsciences.org/docs/4_Sirin_original_8_3.pdf

Brooks, B.A., dkk. (2007). Assessing the Quality of Nursing Work Life, Nursing Administration Quarterly: 31 (2): 152-157

Cascio, W. (2010). Managing Human Resources: Productivity, Quality of Work Life, Profit (8th). New York: McGraw-Hill

Certo, S.C., \& Certo, S.T., (2016). Modern Management, Concepts and Skills, (14th ed). Boston: Pearson

Dossey, B.M., Keegan, L., \& Guzzetta, C.E., (2005). Holistic Nursing: A Handbook for Practice, Massachusetts: Jones \& Bartlett Learning

Eley, R., Eley, D., \& Rogers-Clack, C. (2010). Reasons for entering and leaving nursing: an Australian regional study, Australian Journal Of Advanced Nursing, 28 (1): 6 - 13

Fatehi, B., Amini, I., Karimi, A., \& Azizi, B., (2015). Impact of Quality of Work Life on Job Satisfaction (Case Study: Sport Teachers in Department of Education from Urmia), Research Journal Of Sport Sciences, 3 (1): 15-22

Gay, D.A., \& Lynxwiler, P.J., (2013). Cohort, Spirituality, and Religiosity A Cross-sectional Comparison, Journal of Religion \& Society, 15: 1- 17

Gayathiri, R., \& Ramakrishnan, L., (2013). Quality of Work Life - Linkage with Job Satisfaction and Performance, International Journal of Business and Management Invention, 2 (1): 01-08

Ivancevich, J.M., Konopaske, R., \& Matteson, M.T., (2014). Organizational Behavior and Management, (10th editions). Philadelphia: McGraw-Hill

Kermansaravi1, F., Navidian, A., Rigi, S.N., \& Yaghoubinia, F., (2015). The Relationship between Quality of Work Life and Job Satisfaction

of Faculty Members in Zahedan University of Medical Sciences, Global Journal of Health Science; 7(2); 228-236

Konopaske, R., Ivancevich, J.M., \& Matteson, M.T., (2018), Organizational Behavior and Management, (11th editions). Philadelphia: McGraw-Hill

Lazar, A., (2010). Spirituality and job satisfaction among female Jewish Israeli hospital nurses. Journal of Advanced Nursing, 66(2), 334-344.

Maridi (2006) Hubungan lingkungan kerja dan iklim organisasi dengan kepuasan kerja perawat di Rumah Sakit Islam Pondok Kopi Jakarta Timur, Jakarta: Thesis, Tidak dipublikasikan

Nekouei, M. H., Othman, M.B.T., Masud, J.B., \& Ahmad, A.B., Quality of Work Life and Job Satisfaction among employee in government organizations in Iran, J. Basic. Appl. Sci. Res., 4(1)217-229,

Putra, N.A., (2014). Hubungan Antara Tingkat Kecerdasan Spiritual Dengan Tingkat Depresi Pada Pasien Stroke Di RSUD Dr. R. Goeteng Taroenadibrata Purbalingga, Skripsi, Purwokerto: Universitas Jenderal Soedirman

Rahman, A., \& Makmur, (2015). Perilaku Spiritual Dan Kepuasan Kerja Karyawan Perusahaan Pabrik Kelapa Sawit, Jurnal Ilmiah Cano Ekonomos 4 (1); 19-30

Ramawickrama, J., Opatha, H. H. D. N. P., \& PushpaKumari, (2017). Quality of Work Life, Job Satisfaction, and the Facets of the Relationship between the Two Constructs, International Business Research; 10 (4): 167-182

Reddy. M/ L, Reddy, P.M., (2010). Quality of work life of employees: emerging dimensions, Asian Journal Of Management Research, p. 827- 840

Robbins, S.P., \& Coulter, M., (2017). Management, (13th editions), Boston: Pearson

Robbins, S.P., \& Judge, T.A., (2017). Organizational Behavior, (17th edition), Boston: Pearson

Sinha, C. (2012). Factors Affecting Quality Of Work Life:

Empirical Evidence From Indian Organizations, Australian Journal of Business and Management Research, 1 (11): 31-40

Stamps, P.L (1997), Nurses and work satisfaction, A index for measure. $\left(2^{\text {nd }}\right.$ ed). Chicago : Health Administration 
Stamps, P.L (1997). Nurse and work satisfaction, A index for measure, Health

Administration, 31(4): 194-202.

Wasis. (2008) Pedoman Praktis Penelitian Kesehatan. Jakarta: EGC.

Westera, D.A., (2017). Spirituality in Nursing Practice, The Basics and Beyond, New York: Springer Publishing Company,

WHO. (2006). The Stop TB Strategy : Building on and enhancing DOTS to meet the TB-related Millennium Development Goals. Genewa: World Health Organization.

Wuryanto, Hamid \& Mustikasari (2011) Hubungan antara Lingkungan Kerja dan Karakteristik Individu dengan Kepuasan Kerja Perawat; Studi di Rumah Sakit Umum Daerah Tugurejo, Semarang Tahun 2010, Prosiding: Evidence based practice in nursing science: Unique, diversity, and innovation, Seminar Nasional Keperawatan PPNI Jawa Tengalt, 8 Juni 2011 